\title{
Does flexible migration policy spur competitiveness in the labor market? A case of migrants in the Russian Federation
}

\author{
Azamat Valei $^{1,2} \mathbb{D}$, Suleiman O. Mamman ${ }^{1} \otimes$ \\ ${ }^{1}$ Ural Federal University, \\ 19 Mira St, Yekaterinburg, 620002, Russian Federation \\ ${ }^{2}$ Charles University, \\ 7 Politickych Veznu St, Prague, 111 21, Czech Republic
}

$\bigotimes$ onimisism@gmail.com

\begin{abstract}
With the influx of labor migrants across the globe and developed countries being on the receiving end, countries like the Russian Federation have implemented strict migration policies to check the inflow of these migrants, mainly from low-income countries. However, with theoretical underpin the increase in labor migrants brings about competitiveness in the receiving countries' labor market. The current study evaluates whether the Russian labor migration policy promotes competitiveness given the characteristics of labor migrants in Russia. The study carried out panel data analysis for 14 countries within Russian region and an aggregated data from the rest of the world using the non-stationary heterogeneous panel model and estimators of mean group and pooled mean group. The result first presents strong cointegration between wage levels and labor supply (immigrant, emigrants, and native workforce). The result then reveals a negative effect of immigrants' inflow and native workforce on wage levels in the short run but a positive effect, in the long run, suggesting that the labor migrant's inflow is imperfectly substitutable in the Russian labor market. The result also shows a positive effect of migration policy on wages both in the short and long run, indicating that the strict migration policy can hinder the competitiveness of the labor force in the labor market.
\end{abstract}

Keywords: migration policy, labor market, non-stationary panel, labor migrants, Russia, competitiveness

Article history: received July 17, 2021; revised August 21, 2021; accepted September 10, 2021.

For citation: Valei, A., \& Mamman, S.O. (2021). Does flexible migration policy spur competitiveness in the labor market? A case of migrants in the Russian Federation. RUDN Journal of Economics, 29(4), 673-688. http://dx.doi.org/10.22363/2313-2329-2021-29-4-673-688

(C) Valei A., Mamman S.O., 2021

(c) () This work is licensed under a Creative Commons Attribution 4.0 International License https://creativecommons.org/licenses/by/4.0/ 


\title{
Повышает ли гибкая политика в области трудовой миграции конкурентоспособность на рынке труда? Исследование рынка труда Российской Федерации
}

\author{
А. Валей ${ }^{1,2} \mathbb{D}$, C.O. Мамман ${ }^{1} \otimes$ \\ ${ }^{1}$ Уральский федеральный университет, \\ Российская Федерачия, 620002, Екатеринбург, ул. Мира, д. 19 \\ ${ }^{2}$ Карлов университет, \\ Чешская Республика, 111 21, Прага, ул. Политических наук, д. 7 \\ $\bigotimes$ onimisism@gmail.com
}

\begin{abstract}
Аннотация. В связи с увеличивающимися глобальными потоками трудовых мигрантов по всему миру и в особенности в принимающих их развитых странах, такие государства, как Российская Федерация, проводят строгую миграционную политику для снижения миграционной нагрузки, прежде всего со стороны рабочих из стран с низкими доходами. При этом увеличение числа трудовых мигрантов приводит к повышению конкурентоспособности на рынке труда принимающих стран. В представленном исследовании проводится оценка того, способствует ли российская политика в области трудовой миграции конкурентоспособности с учетом характеристик трудовых мигрантов. Проанализированы панельные данные для 14 стран в пределах российского региона и агрегированные данные из остального мира. Результаты доказывают наличие первоначально сильной зависимости между уровнями заработной платы и предложением рабочей силы (иммигранты, эмигранты и местная рабочая сила), что ведет к отрицательному влиянию притока иммигрантов и местной рабочей силы на уровень заработной платы в краткосрочной перспективе, но положительному - в долгосрочной, хотя и предполагается, что приток трудовых мигрантов несовершенно замещаем на российском рынке труда. Показано положительное влияние миграционной политики на заработную плату, как в краткосрочной, так и в долгосрочной перспективе, принимая во внимание, что строгая миграционная политика может снизить конкурентоспособность рабочей силы на рынке труда.
\end{abstract}

Ключевые слова: миграционная политика, рынок труда, нестационарная панель, трудовые мигранты, Россия, конкурентоспособность

История статьи: поступила в редакцию 17 июля 2021 г.; проверена 21 августа 2021 г.; принята к публикации 10 сентября 2021 г.

Для цитирования: Valei A., Mamman S.O. Does flexible migration policy spur competitiveness in the labor market? A case of migrants in the Russian Federation // Вестник Российского университета дружбы народов. Серия: Экономика. 2021. Т. 29. № 4. С. 673-688. http://dx.doi.org/10.22363/2313-2329-2021-29-4-673-688

\section{Introduction}

Migration has been an aged-long issue globally, with developed and emerging economies being on the receiving end of migrants from less developed countries. Portes (2019) has likened the case of migration to markets. He argued that if people's decision is based on their non-economic self-interest, this will maximize 
their efficiency, productivity, and even their welfare status. Thus, markets can be a suitable mechanism for allocating resources inclusive of human resources.

Over the years, there has been an influx of migrants and refugees across Europe due to demand-pull and supply push factors. These have resulted in various degrees of social vices, congestion, the outflow of funds, and even job substitution. These, among other factors, have compelled some countries to impose a strict migration policy. These policies also cut across regional territories that are significant beneficiaries of free movement within the regions.

Among the countries in Europe that have recorded a high inflow of migrants is Russia, despite enduring political and economic crises such as EU sanctions and dwindling crude oil prices. For instance, it was also estimated that between 1992 and 2017 Kremlin accommodated over 11 million immigrants, with the vast majority arriving from the former Soviet republics (Chudinovskikh, 2018). It was also estimated that the majority of the migrants are from CIS countries, accounting for about $90 \%$ of the total stock of migrants, with the remaining $10 \%$ as migrants from other regions (Karabchuk, Salnikova, 2017). This could be accountable for remittance outflow from the region. For example, in 2010, transfers from individuals in Russia to CIS countries was estimated to amount to US\$11.1 billion; US\$15.14 billion in 2011 andUS\$18.2 billion in 2012, with Chunk of the outflow in 2012 going to Uzbekistan (31.1\%), Tajikistan (20\%), Ukraine (14.7\%) and Kyrgyzstan (10\%). ${ }^{1}$ The responsive factor for this migration flow surge can be attributed to the low quality of life in the country of origin, high wage differentials between the countries, among other factors.

Conversely, Russia has also enjoyed some overwhelming economic growth across the regions as, despite the current crisis, it still stood as the 11th largest economy based on GDP in 2019. Thus, it is presumed that Russia still accommodates migrants, especially unskilled labor. Andrienko and Guriev (2005) argued that international migration is becoming a prerequisite for sustainable development in Russia chiefly to demographic factors such as the aging working population. Further stating that an initial peek of the Kremlin's economy indicates that it enjoys a relative advantage in natural resources. Thus, declining population growth may not harm economic growth.

Nonetheless, with the uncertainty in the minerals sector, it becomes imperative to diversify the economy to avoid a stiffer crisis that may arise in the future. However, the expansion may require human capital, which the aging native workforce might be insufficient, thereby increasing the demand for the labor force. The Russian informal sector may be receptive to labor migrants and could prefer the services to natives given its cheap labor cost.

One major factor that might impede this development is the labor migration policy which requires labor migrants to obtain a Russian work permit to work in Russian territory. Understandably, Kremlin is trying to control the influx of migrants to protect the native workforce from losing their jobs to the cheap labor force from the migrants as well as other likely social vices. Andrienko and Guriev (2005) ex-

${ }^{1}$ Chawryło, K. (2014). Russia tightens up residence regulations for CIS citizens. Retrieved January 15, 2014, from https://www.osw.waw.pl/en/publikacje/analyses/2014-01-15/russia-tightensresidence-regulations-cis-citizens 
plain that the critical impediments to migration in Russian territory are administrative controls, real estate, and underdeveloped financial markets.

Given this restriction, it is understandable that Russia faces a potential trade-off between economic expansion and citizen/territorial fortification. In the face of these dynamics, the current study is motivated to determine whether migration legislation brings about economic competitiveness in the Russian territory. In doing this, the study will evaluate the system to determine whether the migrants are complementary or substitutable in the labor market. Furthermore, it is essential to know how sensitive the wages are to immigrants and emigrants from Russian accessing the market from the demand and supply side. Lastly, it is essential to determine whether competitiveness (if identified) in the labor market is sustainable for long-term gains.

\section{Literature review}

Migration policy and pattern in Russia. Before 2014, Russia was believed to have a more open labor migration policy seen as the influx of migrants into the region, with Russian among the top countries to host migrants in Europe and a number in the CIS region. As outlined by (Ivakhnyuk, 2013), Russian migration policy has been itinerant from an open policy based on the free-market method, especially in the early 90 s, to a more restrictive policy in the early 2000 s and above. However, these policies are a bit relaxed for CIS migrants. A cursory look at the Russian Federal State Statistics Service (Rosstat) reveals that Kremlin has a falling migration figure (both immigrants and emigrants) from 1997 to 2010.

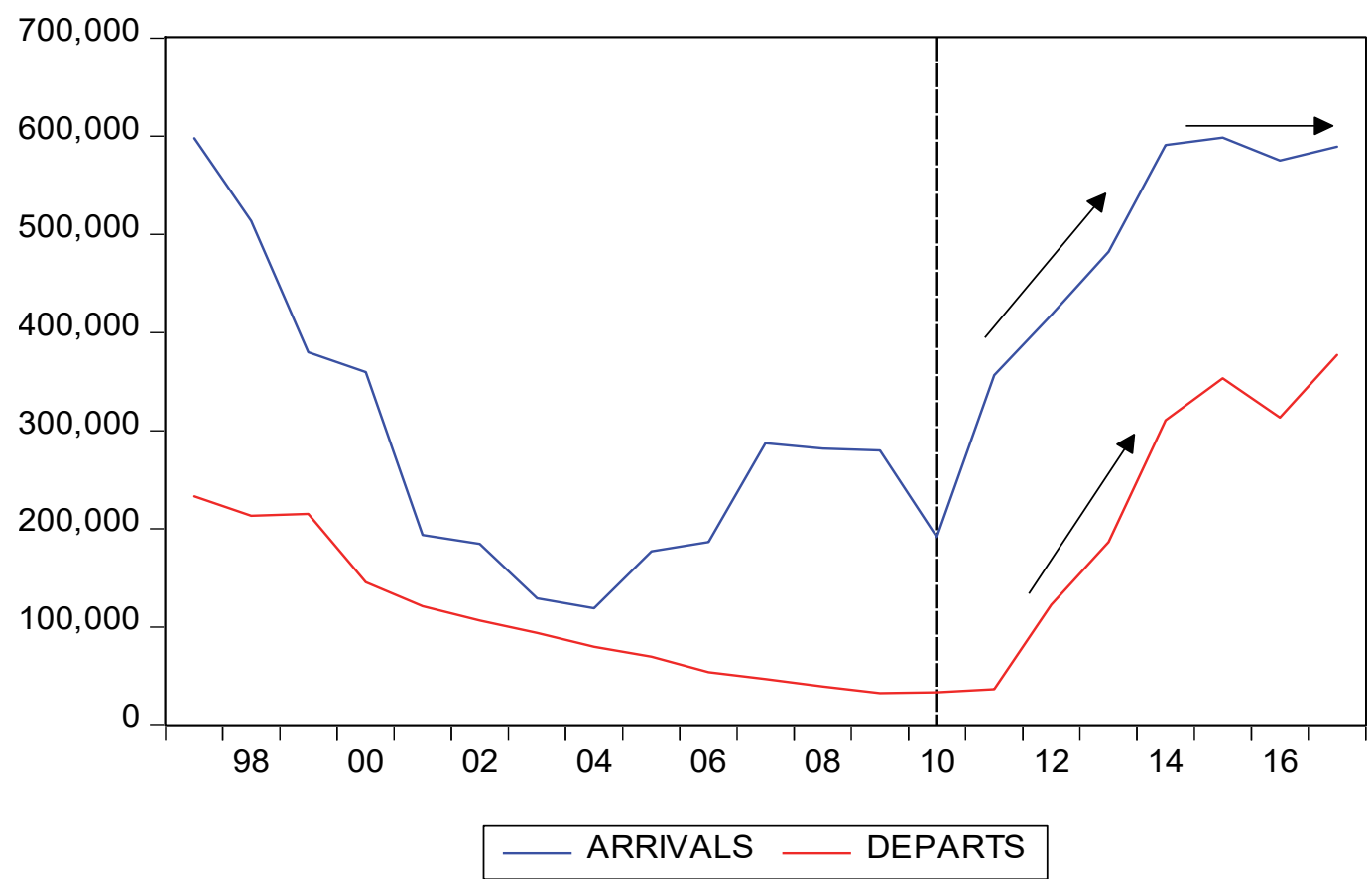

Figure 1. Arrivals and departure from Russia, 1998-2016, thousands of people

Source: Federal State Statistic Service. Retrieved October 25, 2020, from https://eng.gks.ru/

The view from Figure 1 further indicates that after 2010 was crucial in the Russian economy as it witnessed an upsurge in migration flow with a growth 
rate between 2010 to 2011 reaching about $86.03 \%$ for arrivals while departure had an overwhelming figure of about 233.74\% between 2011 and 2012 (Table 1). However, arrivals were still relatively higher than departure, evident from the net migration pattern in Figure 2. More revealing was the flattening of both immigration and emigration after 2014. This observation is strategic because it was the same period when the government to curb migration implemented its new migration policy.

Table 1

Annual of percentage change in migration flows

\begin{tabular}{ccccccccccc}
\hline Year & 2008 & 2009 & 2010 & 2011 & 2012 & 2013 & 2014 & 2015 & 2016 & 2017 \\
\hline Arrivals & -1.86 & -0.61 & -31.53 & 86.03 & 17.15 & 15.46 & 22.52 & 1.32 & -3.92 & 2.41 \\
\hline Departure & -15.96 & -17.84 & 3.45 & 9.54 & 233.74 & 51.84 & 66.59 & 13.76 & -11.33 & 20.42 \\
\hline
\end{tabular}

Source: Federal State Statistic Service. Retrieved October 25, 2020, from https://eng.gks.ru/

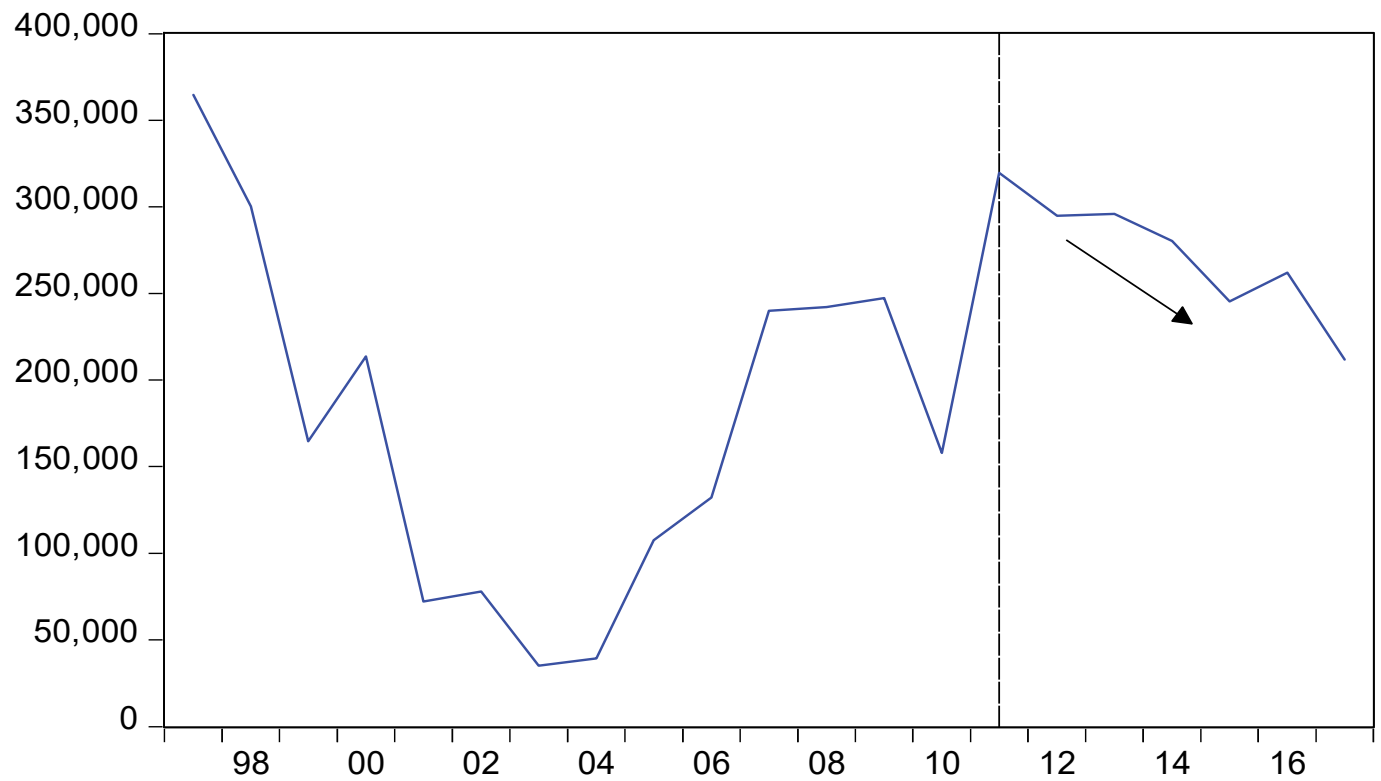

Figure 2. Net migration, 1998-2016, thousands of people

Source: Federal State Statistic Service. Retrieved October 25, 2020, from https://eng.gks.ru/

Some of the key highlights from the new migration to Russian territory, as extracted from (Karabchuk, Salnikova, 2017), is that a migrant can obtain permission to carry out a paid job/activity in Russian territory with two approaches of either work permit or patent. The work permit is a document that authorizes a migrant to work temporarily in Russian territory. This migrant is usually a foreign citizen who is from outside the visa-free region of CIS members. To obtain the work permit, a migrant must provide the State authorities with a draft employment agreement (signed and stamped) by the employer before the migrants enter Russian territory.

Theoretical framework. Arguably, the approach to understanding international migration could be viewed as a consequence of imbalances on a developmental level between two economies (Nyberg-Sørensen et al., 2002). Arguably, it is believed that international migration is a broad and complex concept such that no sin- 
gle economic theory can explain it. The causes of international migration are better understood by incorporating a variety of perspectives and factors. These economies include the sending (developing economy) and the receiving (developed economy). According to a document by the European Commission on why people migrate, the document outlined eight theories explaining why people migrate. The prominent one amongst them applied to this study is the neoclassical theory. The theory assumes that labor markets and economies move towards equilibrium in the long run through trade and migration. It considers migrants as purely rational actors. More so, migrants move from societies where labor is abundant, and wages are low to societies where labor is scarce, and wages are high. The classical theory explains that migration occurs due to a combination of supply-push and demand-pull factors. The supply-push factors may include: low wages, unemployment, and low productivity, while the demand-pull factors may include employment opportunities, good working conditions, higher wages, and high productivity, among others.

The further assumption, in theory, explains that the primary determining factor of how wages and employment are affected by migrants' immigrants is hinged on the level at which the new immigrants complement or substitute for the existing workers. In the short run, wages may fall for workers seen as substitutable by immigrants, while wages may increase for native workers whose skills are complemented by new workers. However, the theory does not explain the impact of migration on the host economies' productivity. However, migration could be seen as a supply shock to the factor of production of labor supply (Chojnicki, 2004). Thus, Borjas (1995), in his argument on the positive theory of migration, has demonstrated that the inflow of foreign labor not accompanied by physical capital reduces the equilibrium wage rate and further leads to redistribution. In summary, he stressed a trade between efficiency gains and the transfer of wealth from home workers to migrants. They noted that the former is associated with a surplus of immigrants workers.

Extant literature. There are pretty extensive works on migration impact on economic factors both within and outside the Russian region. Because of the peculiarities of each economic system, the conclusions are divergent, with some arguing that migration has a positive impact on critical indicators such as employment, wages, and even welfare of the native workforce. In contrast, some argued that they harm these indicators. Some believe that while it affects these factors, they may not respond proportionately to migration, and even some cases are less sensitive. Some works are also of the view that it depends on the substitutability of the migrants to the native workforce. In some instances, the native workforce is protected, so the impact is on the fellow migrants in the market. For instance, the study of Borjas $(1999 ; 2003)$ has vehemently argued that inflow of labor migrants have a solid and pronounced effect on the host wage pattern as it tends to offset the labor market through substitutability of the labor force, but contextually, the study of Card and Altonji (1990; 1991), are of the divergent view, arguing that the effect of labor migrants is not resilient to offset host labor market outcomes. In terms of substitutability, Ottaviano and Peri (2012) find evidence of high though imperfect substitutability between labor migrants and the host workforce within some demographic characteristics such as age and education. In line with this (Manacorda et al., 2012) also found evidence of imperfect substitution be- 
tween host and labor migrants informed by age-education groups as immigration suppresses the remunerations of previous immigrants compared to the host workforce. The study also found that recent immigrants are more reactive to new arrivals than old immigrants.

Lundborg (2013) has indicated that immigrants' workforce from countries with the same income level as the host country should not wield downward pressure on wage levels but rather those from relatively lower wage levels. Based on this, the study argued that the free flow of migrants from lower wages countries could drop wages in the short run, but the drop will subsequently even out, and wage levels will return to their natural level in the long run. Some studies have suggested the use of wage settings and caps to protect the native workforce. For instance, the study of Edo and Rapoport (2019) argued that the effect of labor migrants in the host labor market is more harmful in countries where the adequate minimum wage is relatively low or ineffective but further noted that sufficiently high wages tend to protect host workforce from an adverse effect of migrants on wage and employment levels.

In Russia, the study of Eldyaeva et al. (2019) reveals that migration has both positive and negative effects on the socio-economic development in the Russian region. Also, that migration has a peculiar effect in each region in terms of scope and intensity as migration flows are characterized by heterogeneity in their spatial and temporal dynamics. Further highlighting that age, income, and educational level may determine the duration of labor migration in Russia. A related study (Lazareva, 2015) used natural experiments to evaluate the assimilation and local labor market effects of migrants in Russia. The findings show a negative effect of the inflow of migrants on employment and labor force participation but not on wages. Also, the study found that male immigrants are fully assimilated into the labor market than female migrants whose integration is slow due to significant wage and employment gaps.

Lazareva \& Sonin (2008) identify that while an exogenous factor determines migration, the choice of location is endogenous. In line with this, the study found evidence that migrants have better opportunities in terms of employment in regions with a low percentage of migrants than in regions with a higher percentage of migrants. The findings are consistent with the hypothesis that migrants choose regions with high demand for their skills, and the competition is with their fellow migrants rather than the indigenes. On the supply side of migration, that is, emigration from the host countries (Elsner, 2015), found evidence that emigration has a significant dual effect on the wages of non-emigrants. On the one hand, it directly makes some groups of workers scarcer than others and indirectly affecting the changes in aggregate productivity. This further implies that the average effect on wages is positive in the sending countries, which makes it have a dual effect of positive and negative effects. Similarly, the workers that gain from these dynamics are the worker with workers with different skills lose.

\section{Methodology}

The study carries out a time series analysis to determine whether the flexible migration laws that spur an influx of immigrants bring about competition and determine the long-term effects' sustainability. The study is anchored on the neoclas- 
sical theory of migration and positive theory of immigration policy by Borja (1995). Herewith is the assumption that competitiveness is achieved when the labor supply from the immigrants is substitutable rather than complimentary, and whether the increase in immigrants' labor force increases productivity. Only then can we assume that there is competitiveness from the labor supply. Based on this, we assume that competitiveness may be achieved when there is a negative effect of labor supply on wage levels in the short run and a positive effect of labor supply on wage levels in the long run after the market clears. That is, complete absorption of excess supply in the market and smoothened short-run shock. Thus, from the above, the study functional equation is given.

$$
\begin{gathered}
W A G_{i t}=\delta_{i}+\gamma_{0} I M M_{i, t}+\gamma_{1} E M M_{i, t}+ \\
+\gamma_{2} N A W_{i t}+\gamma_{3} I M M_{i, t} * D_{t}+\gamma_{4} I N F_{i t}+\varepsilon_{i, t} \ldots \ldots .1,
\end{gathered}
$$

where $W A G_{t}$ is wage levels (accrued nominal wages) which is time-variant and cross-sectional invariant; $I M M_{i, t}$ - number of immigrants into Russia across $i$ countries at time $t ; E_{m m i, t}$ - number of emigrants from Russia across $i$ countries at time $t ; D_{t}-$ a dummy variable introduced to capture the periods of restrictive and less restrictive labor migration laws; $I M M_{i, t} * D_{t}$ is dummy interactive variable with immigration flows; $I N F_{i t}$ is the price level $\varepsilon_{i, t}$ is the error term.

To account for endogeneity and autocorrelation as theoretically informed and heterogeneity given $T>N$, the heterogeneous non-stationary panel model will be employed while adopting the estimation technique of mean group (Pesaran, Smith, 1995) and pool mean group (Pesaran et al., 1999). Thus, the above model will be transformed into a dynamic model. Similarly, the cointegration test will be conducted to determine whether the variables have a common trend, which we intend to use to detect the sustainability of competitiveness in the long run.

\section{Data}

Annual data from 1997 to 2017 on migration history (to and from Russia) on 14 countries in the Russian region and an aggregated data from the rest of the world. These data will be sourced from the Russian Federal State Statistics Service (Rosstat) database. For wage level, the accrued annual nominal wages per employee (in rubles) was used, National working population, the number of the employed population (15 to 72 years) measured in millions of persons was used, for the migration data, the number of arrivals and departure measured in persons was used. A dummy to capture the period of less restrictive and more restrictive laws was used. The Inflation rate was used to capture the price level.

Abbreviation definition: NWF - native workforce; IMM - immigrants; EMI - emigrants; POL - migration policy; IMM*POL - interactive variable (immigrants and migration policy).

\section{Results and discussion}

Panel unit root test. All the variables were logged except for the Inflation rate and dummy. They were subjected to various panel unit root tests such as Harris and Tzavalis, Breitung, Levin, Lin, Chu, Pesaran and Shin, Fisher-type (Choi), 
and Hadri. The results indicating a mixture of $I(1)$ and $I(0)$ level of stationarity (documented in the log file) and a summary presented below.

Table 2

Cross-sectional independence panel unit root test

\begin{tabular}{cccc}
\hline Variable & Levin - Lin - Chu & Im - Pesaran - Shin & Hadri \\
\hline Wages & $I(0)$ & $I(0)$ & $I(0)$ \\
NWF & $I(0)$ & $I(0)$ & $I(0)$ \\
Immigrants & $I(0)$ & $I(1)$ & $I(0)$ \\
Emigrants & $I(1)$ & $I(1)$ & $I(0)$ \\
Inflation & $I(1)$ & $I(0)$ & $I(0)$ \\
\hline
\end{tabular}

Source: compiled by the authors.

Cross-sectional dependence panel unit root test

\begin{tabular}{cccc}
\hline Variable & Harris - Tzavalis & Breitung & Fisher \\
\hline Wages & $I(1)$ & $I(1)$ & $I(0)$ \\
NWF & $I(1)$ & $I(1)$ & $I(1)$ \\
Immigrants & $I(1)$ & $I(0)$ & $I(0)$ \\
Emigrants & $I(1)$ & $I(0)$ & $I(1)$ \\
Inflation & $I(0)$ & $I(1)$ & $I(0)$ \\
\hline
\end{tabular}

Source: compiled by the authors.

Panel cointegration test. Three-panel cointegration tests were carried out to ascertain whether the wage levels and the labor force have a common trend. This was motivated by the mixed stationarity obtained from the unit root test as indicated in Tables 2 and 3. The result shows a strong cointegration indicating a long-run relationship between the labor supply and wage levels. This outcome further indicates the sustainability of wages levels with the dynamics of the migrants' and natives' workforce.

Table 4

Panel cointegration test

\begin{tabular}{cc}
\hline Cointegration test & Statistics \\
\hline Pedroni & $-14.13^{\star \star \star}$ \\
Kao & $-3.94^{\star \star \star}$ \\
Westerlund & $-1.52^{\star}$ \\
\hline
\end{tabular}

Note: ${ }^{* \star} p<0.01,{ }^{\star \star} p<0.05,{ }^{\star} p<0.1$.

Source: compiled by the authors.

All the tests show strong evidence of cointegration. The study proceeds to estimate the equations using the non-stationary panel heterogeneous model with the pool mean group (PMG) and mean group (MG) estimators (Pesaran et al., 1999; Pesaran, Smith, 1995). These estimators are known to capture heterogeneity and account for endogeneity in a model. However, PMG is a less restrictive estimator. It allows the intercept, short-run coefficients, and error variances to differ across the groups but constrains the long-run coefficients to be equal. 
PMG estimates (short-run estimates)

\begin{tabular}{cccccc}
\hline Variables & Model 1 & Model 2 & Model 3 & Model 4 & Model 5 \\
\hline ECT & $-0.247^{\star \star \star}$ & $-0.249^{\star \star \star}$ & $-0.245^{\star \star \star}$ & $-0.248^{\star \star \star}$ & $-0.259^{\star \star \star}$ \\
& $(0.00281)$ & $(0.00361)$ & $(0.00369)$ & $(0.00358)$ & $(0.00609)$ \\
\hline D.NWF & $-1.029^{\star \star \star}$ & $-1.024^{\star \star \star}$ & $-0.977^{\star \star \star}$ & $-0.950^{\star \star \star}$ & $-0.761^{\star \star \star}$ \\
& $(0.0666)$ & $(0.0854)$ & $(0.0863)$ & $(0.0789)$ & $(0.0806)$ \\
\hline D.IMM & $-0.0130^{\star \star \star}$ & $-0.0185^{\star \star \star}$ & $-0.0208^{\star \star \star}$ & $-0.0244^{\star \star \star}$ & $-0.0324^{\star \star \star}$ \\
& $(0.00350)$ & $(0.00337)$ & $(0.00313)$ & $(0.00350)$ & $(0.00313)$ \\
\hline D.EMI & & $0.0178^{\star \star \star}$ & $0.0151^{\star \star \star}$ & 0.00409 & -0.00582 \\
& & $(0.00329)$ & $(0.00328)$ & $(0.00335)$ & $(0.00412)$ \\
\hline POL & & $0.703^{\star \star \star}$ & $0.467^{\star \star \star}$ & $0.207^{\star \star \star}$ \\
& & $(0.0108)$ & $(0.0210)$ & $(0.0139)$ \\
\hline D.IMM POL & & & $0.00356^{\star \star \star}$ & $0.00338^{\star \star \star}$ \\
& & & $(0.000429)$ & $(0.000496)$ \\
\hline D.Inflation & & & & $0.000507^{\star \star \star}$ \\
& & & & $(4.97 e-05)$ \\
\hline Constant & $-69.50^{\star \star \star}$ & $-69.47^{\star \star \star}$ & $-68.80^{\star \star \star}$ & $-72.48^{\star \star \star}$ & $-70.24^{\star \star \star}$ \\
& $(0.792)$ & $(1.010)$ & $(1.037)$ & $(1.050)$ & $(1.657)$ \\
\hline Observations & 270 & 270 & & 270 & 270 \\
\hline
\end{tabular}

Note: 1) standard errors in parentheses; 2) ${ }^{* *} p<0.01,{ }^{* *} p<0.05,{ }^{*} p<0.1$.

Source: compiled by the authors.

Table 6

MG estimates (short-run estimates)

\begin{tabular}{cccccc}
\hline Variables & Model 1 & Model 2 & Model 3 & Model 4 & Model 5 \\
\hline ECT & $-0.249^{\star \star \star}$ & $-0.256^{\star \star \star}$ & $-0.257^{\star \star \star}$ & $-0.260^{\star \star \star}$ & $-0.255^{\star \star \star}$ \\
& $(0.00263)$ & $(0.00593)$ & $(0.00577)$ & $(0.00694)$ & $(0.0133)$ \\
\hline D.NWF & $-1.059^{\star \star \star}$ & $-1.053^{\star \star \star}$ & $-1.069^{\star \star \star}$ & $-0.892^{\star \star \star}$ & -0.167 \\
& $(0.0720)$ & $(0.122)$ & $(0.120)$ & $(0.134)$ & $(0.217)$ \\
\hline D.IMM & $-0.0138^{\star \star \star}$ & $-0.0305^{\star \star \star}$ & $-0.0318^{\star \star \star}$ & $-0.0375^{\star \star \star}$ & $-0.0645^{\star \star \star}$ \\
& $(0.00417)$ & $(0.00611)$ & $(0.00642)$ & $(0.00765)$ & $(0.0153)$ \\
\hline D.EMI & & $0.0191^{\star \star \star}$ & $0.0188^{\star \star \star}$ & 0.00618 & -0.0154 \\
& & $(0.00474)$ & $(0.00509)$ & $(0.00543)$ & $(0.0102)$ \\
\hline POL & & -0.00345 & -0.400 & -0.743 \\
& & & $(0.00288)$ & $(1.055)$ & $(1.343)$ \\
\hline D.IMM*POL & & & $0.00602^{\star \star \star}$ & $0.00837^{\star \star \star}$ \\
& & & $(0.00113)$ & $(0.00233)$ \\
\hline D.Inflation & & & & $0.00104^{\star \star \star}$ \\
& & & & & $(0.000130)$ \\
\hline Constant & $-70.13^{\star \star \star}$ & $-71.97^{\star \star \star}$ & $-72.90^{\star \star \star}$ & $-77.65^{\star \star \star}$ & $-67.00^{\star \star \star}$ \\
& $(1.031)$ & $(1.990)$ & $(1.963)$ & $(2.392)$ & $(4.746)$ \\
\hline Observations & 270 & 270 & 270 & 270 & 270 \\
\hline
\end{tabular}

Note: 1) standard errors in parentheses; 2) ${ }^{* \star *} p<0.01,{ }^{* *} p<0.05,{ }^{\star} p<0.1$.

Source: compiled by the authors.

However, the MG allows the intercepts, slope coefficients, and error variances to differ across groups. More so, the Hausman pairwise was employed to test to determine the most consistent and efficient estimator among the two. Five model series were estimated for each category of the estimators (PMG and MG), 
starting with the baseline model of wage rate as a function of the workforce of both immigrants and native workforce.

Tables 5 and 6 presents short-run estimates for PMG and MG, while Table 7 and 8 present their long-run estimates for PMG and MG. However, the pairwise Hausman test could not be defined, possibly given that the coefficients from the two estimators are highly identical. Though, the study will rely on the estimates from the PMG to allow for long-run estimates to be equal as we assume that the effect of migrants to Russia's labor market is the same irrespective of the migrants' home country as the rules regarding the skills and qualification apply to all migrants.

Estimates from model 1 in Table 5 reveal that in the short run, with a supply shock in the labor market, an increase in the labor force (both domestic and immigrants) will have a consequential adverse effect on the wage levels. For instance, a percentage increase in the domestic labor force (NWF) will reduce the nominal wage level by about $1 \%$. Likewise, a percentage increase in the immigrants' workforce leads to about $0.01 \%$ reduction in the wage levels. This also implies that while the domestic labor supply is elastic, the immigrant labor supply is inelastic. Thus, the implications of this outcome imply that the labor market is competitive with the interaction of domestic and immigrants labor force in the market in the short run. Nevertheless, because it is highly inelastic, we could say that the relation between the native workforce and migrant's workforce is imperfect substitutability which conforms with the study of Ottaviano and Peri (2012), who found a similar outcome.

Table 7

PMG estimates (long run estimates)

\begin{tabular}{cccccc}
\hline Variables & Model 1 & Model 2 & Model 3 & Model 4 & Model 5 \\
\hline NMF & $16.13^{\star \star \star}$ & $15.99^{\star \star \star}$ & $16.07^{\star \star \star}$ & $16.72^{\star \star \star}$ & $15.52^{\star \star \star}$ \\
& $(0.332)$ & $(0.320)$ & $(0.332)$ & $(0.314)$ & $(0.373)$ \\
\hline IMM & $0.0385^{\star \star \star}$ & $0.0382^{\star \star \star}$ & $0.0456^{\star \star \star}$ & $0.0411^{\star \star \star}$ & $0.104^{\star \star \star}$ \\
& $(0.0118)$ & $(0.0141)$ & $(0.0155)$ & $(0.0144)$ & $(0.0165)$ \\
\hline EMI & $-0.0117^{\star}$ & $7.06 \mathrm{e}-05$ & 0.0157 & 0.00893 \\
& & $(0.00663)$ & $(0.0105)$ & $(0.0101)$ & $(0.00931)$ \\
\hline POL & & -2.918 & -3.972 & -2.109 \\
& & $(0)$ & $(0)$ & $(0)$ \\
\hline IMM*POL & & & $0.201^{\star}$ & 0.123 \\
& & & & $(0.120)$ & $(0.113)$ \\
\hline Inflation & & & & $-0.00835^{\star \star \star}$ \\
& & & & 270 & $(0.00162)$ \\
\hline Observations & 270 & 270 & & 270 \\
\hline
\end{tabular}

Note: 1) standard errors in parentheses; 2$){ }^{\star \star \star} p<0.01,{ }^{\star \star} p<0.05,{ }^{\star} p<0.1$.

Source: compiled by the authors.

The error correction term was negative and highly significant, indicating a solid cointegration of the series. The values indicate a fair speed of adjustment of about $24.7 \%$ (PMG) short-run disequilibrium corrected towards long-run equilibrium. However, the long-run components of the estimates reveal a divergent outlook with the supply of labor from both domestic and immigrant, indicating 
a positive impact on wage level. For instance, in Table 7, the estimates in model 1 reveal that wages levels increase by about $16 \%$ with a percentage increase in the domestic labor force. In comparison, wages levels increase by about $0.04 \%$ with an increase in the immigrant workforce. The results also show a strong elasticity of domestic workforce and wage levels while the immigrant workforce remains elastic, indicating the wages levels are not very sensitive to inflow immigrants.

Table 8

MG estimates (long run estimates)

\begin{tabular}{cccccc}
\hline Variables & Model 1 & Model 2 & Model 3 & Model 4 & Model 5 \\
\hline NMF & $16.13^{\star \star \star}$ & $16.12^{\star \star \star}$ & $16.24^{\star \star \star}$ & $17.10^{\star \star \star}$ & $15.00^{\star \star \star}$ \\
& $(0.159)$ & $(0.210)$ & $(0.212)$ & $(0.255)$ & $(0.716)$ \\
\hline IMM & $0.0489^{\star \star \star}$ & $0.0763^{\star \star}$ & $0.0782^{\star \star}$ & 0.0613 & $0.235^{\star \star \star}$ \\
& $(0.0112)$ & $(0.0344)$ & $(0.0355)$ & $(0.0419)$ & $(0.0632)$ \\
\hline EMI & $-0.0496^{\star \star \star}$ & $-0.0550^{\star \star \star}$ & -0.0286 & -0.0548 \\
& & $(0.0154)$ & $(0.0213)$ & $(0.0249)$ & $(0.0409)$ \\
\hline POL & & -0.0134 & -1.198 & -1.723 \\
& & $(0.0110)$ & $(4.024)$ & $(5.737)$ \\
\hline IMM*POL & & & 0.120 & 0.184 \\
& & & & $(0.472)$ & $(0.808)$ \\
\hline Inflation & & & & -0.00394 \\
& & & & & $(0.00371)$ \\
\hline Observations & 270 & & & \\
\hline
\end{tabular}

Note: 1) standard errors in parentheses; 2$){ }^{\star \star \star} p<0.01,{ }^{\star \star} p<0.05,{ }^{\star} p<0.1$.

Source: compiled by the authors.

This further indicates that in the long run, the market must have absorbed the supply shocks in the market such that reversal of the earlier behavior of the market is now observed. This is in line with the findings of Lundborg (2013), which indicates that the free flow of migrants from lower-wage countries could force down wages in the short run but with the possibility of reversal to natural rate in the long. The current estimates may also indicate that an increase in the labor force will increase wage levels rather than bringing it down because the supply shock must have been absorbed in the market, and the migrants assimilated into the labor market. This also conforms with the theory that the labor force increases productivity in the long run, which then transmits to an increase in nominal wage levels.

This indicates that all things have been equal. The Russian labor market is less competitive but not complementary (imperfectly substitutable) as the increase in labor in the short term relatively brings down the wage levels. The consequent implication of this outcome is that the Russian labor market is vulnerable to the short-run supply shock of labor migrants. However, the wages are also more responsive to the domestic labor force as estimates have indicated that wage levels are insensitive to immigrants' labor supply. The native workers dominate the skilled and semi-skilled and even the unskilled work in the Russian market and have been demonstrated by the high elasticity observed.

In model 2 of Table 5, we could see the estimated emigrants as a control variable to see its effect in the labor market. As expected, while the native work- 
force and immigrants retained their signs and significance as observed in model 1 , emigration shows a positive and significant sign in the short run. At the same time, it was negative and significant in the long run (see model 2 of Table 7). This means that with a shock in the short-run, an outflow of the labor force in the labor market drives nominal wage levels upward. However, this increase is not as much as reducing wages (as immigrants enter the labor market).

However, due to the absorption of the shock in the long run, through the expansion of productive capacity, an outflow of migrants from the labor market will harm the wage level as the market is now producing at a sub-optimal level. Elsner (2015) also found similar evidence, which indicates that an increase in emigration has a dual effect of increasing average wages in the sending country. However, productivity can also reduce, especially if the supply of a particular workforce is scarce. However, it does not specify whether these effects were short or long run. The estimate from the current study has indicated that both short-run and long-run estimates show that wage levels are inelastic to an outflow of migrants from the market. The estimate also reveals that wage levels are more sensitive to the inflow of migrants than the outflow of migrants in the Russian labor market.

In model 3, episodes of government migration policy (from less restrictive to more restrictive approach) were added to the model through a dummy. The estimate for government policy indicates that in the short run, an increase (a strict government policy) has a positive effect on wages levels (increases wage level). Because of the inability of the labor market to absorb the shocks in the short run, strict government policy constricts the labor market, which makes it difficult for an additional inflow of labor force in the market, thereby regulating the labor market (maintaining or driving wage levels up). Thus, when the migration law regulates the market, the labor market is rendered less competitive, especially in the short run. However, the long-run coefficient (from Table 7) indicates otherwise, which shows that the more restrictive the policy is likely to reduce the nominal wages. It is worth noting that while the short-run effect is significant, such cannot be said of the long run. This also indicates that the migration effect is powerful in the short run than in the long run. Nevertheless, with stability and absorption of the short-run shock, in the long run, further tightening of the labor market restricts the market from achieving optimality in production. The estimate conforms to Borja's positive theory of migration, which indicates that the absence of a strict migration policy does not improve productivity and wage level as when there is no such regulation.

To see how migration labor laws directly affect immigrants' effect in the labor market, an interactive dummy variable was included in model 4 (Immigrant*Dummy). The result reveals that, unlike the un-interactive immigrants' inflow which hurts nominal wage levels in the short run, the interactive variable indicates a positive effect on wage levels in the short run. Similarly, the interactive variable also positively affects the wage levels in the long run, analogous to the effect of immigrants' inflow in the labor market. This implies that the migration policy has a strong effect on the behavior of immigrants' inflow in the labor market in the short-run since it constricts the supply of labor force, the increase in the labor supply from the immigrants is not strong enough to alter the distribution of wage levels. This then makes the market less or uncompetitive in the short run. However, this effect is sustained in the long run. 
In the final model, price level (inflation) was included as a control in the model. This is because of the solid theoretical link between price levels and wage levels. An increase in the price level leads to an increase in nominal wage and may not change real wage if the changes in the price level lead to a proportional change in nominal wage. The result reveals that an increase in the inflation rate in the short run leads to an increase in nominal wage levels, although this is highly inelastic but significant. However, in the long run, an increase in the inflation rate reduces the wage levels, as indicated by the estimates.

\section{Conclusion and recommendations}

With the enduring argument on the topical issue of migration regarding the gains and consequences, the study analyzed the impact of migrants' inflow from CIS countries and the rest of the world in the Russian labor market. From a theoretical perspective, migration inflow could be seen as a supply shock of the labor force in labor with the short-run consequence of bringing down wage levels due to lags in assimilating the supply. Nevertheless, wage level is assumed to reverse to normalcy in the long run when the labor force must have been assimilated and subsequently increases wage level. However, there are various dimensions to these simplistic assumptions. Most times, most of the labor force are semi or low-skilled migrants, which maybe be seen as complementary to the existing native labor force. Most times, especially in countries like Russia, employing a foreign skilled labor force is tricky, especially when there is an alternative native to do the work.

Also, most times, the inflow and activities of labor migrants are constrained by strict labor migration laws, which might be seen as a severe impediment to achieving competitiveness, as argued by Borja in its positive theory of migration. Notwithstanding, it has also been argued that migrants' impacts could significantly offset the labor market. At the same time, some authors are of the divergent view that the impact of labor migrants cannot be significant enough to offset the labor market. Some even argued that the inflow of migrants is seen as an imperfect substitution in the labor market.

Thus, in the current study, it was observed from the estimate that the immigrant's labor force brings about competitiveness (though imperfect substitution) in the Russian labor market in the short run and, as theoretically argued. However, the assimilation of the labor migrants, in the long run, can bring about increased productivity. More so, the supply of migrants' labor force is inelastic both in the short run and long run short, which is an indication that they have been regulated. This assumption is further supported by the indicator of migration policy which shows that strict migration policy regulates the inflow of migrants in the labor market and neutralizes their effect in the market. The cointegration result also indicates that the competitiveness in the labor market is sustainable and leads to improved wage levels in the long run. The result also indicates that the price level (inflation rate) affects wage levels. This effect is significant though inelastic in both the short-run and long-run.

This result may imply that all things have been equal. An inflow of migrants can bring about competitiveness in the short run by bringing down wage levels. This outcome may also bring about increased productivity when the labor migrants 
must have been absorbed in the labor market. This further indicates that the inflow of labor migrants into Russian labor are seen as imperfect substitutes, which may have lacked the resilience to offset the labor market. Lastly, given the strict migration policy, it may be challenging to achieve competitiveness in the labor market. Hence, the possibility of tranquilizing the migration law may be about the visualized gains of competitiveness in the Russian labor market.

\section{References}

Altonji, J., \& Card, D. (1991). The effects of immigration on the labor market outcomes of less-skilled natives. Immigration, Trade, and the Labor Market (pp. 201-234). National Bureau of Economic Retrieved October 25, 2020, from https://econpapers.repec.org/RePEc:nbr:nberch:11773

Andrienko, Yu., \& Guriev, S. (2005). Understanding migration in Russia. Center for Economic and Financial Research at New Economic School.

Borjas, G.J. (1995). The economic benefits from immigration. Journal of Economic Perspectives, 9(2), 3-22. https://doi.org/10.1257/jep.9.2.3

Borjas, G.J. (1999). The economic analysis of immigration. Handbook of Labor Economics, 3(Part A), 1697-1760. https://doi.org/10.1016/S1573-4463(99)03009-6

Borjas, G.J. (2003). The labor demand curve is downward sloping: Reexamining the impact of immigration on the labor market. Quarterly Journal of Economics, 118(4), 1335-1374. https://doi.org/10.1162/003355303322552810

Card, D. (1990). The impact of the Mariel Boatlift on the Miami labor market. ILR Review, 43(2), 245-257. https://doi.org/10.1177/001979399004300205

Chojnicki, X. (2004). The economic impact of immigration for the host countries. Brussels Economic Review, 47(1), 9-28.

Chudinovskikh, O. (2018). Work Session on Migration Statistics Item 3 of the Provisional Agenda Integration of Data from Censuses, Administrative Sources and Surveys for Measuring Migration Statistics on International Migration in Russia: The Current Situation*." Geneva. Retrieved October 25, 2020, from https://unece.org/fileadmin/DAM/stats/documents/ece/ces/ge.10/2018/mtg1/RUS_Chu dinovskikh_ENG.pdf

Edo, A., \& Rapoport, H. (2019). Minimum wages and the labor market effects of immigration. Labour Economics, 61, 101753. https://doi.org/10.1016/j.labeco.2019.101753

Eldyaeva, N.A., Kovanova, E.S., Lebedinskaya, O.G., \& Tenetova, E.P. (2019). The specifics of migration in Russian regions. SHS Web of Conferences, 62, 06004. https://doi.org/10.1051/shsconf/20196206004

Elsner, B. (2015). Does emigration increase the wages of non-emigrants in sending countries? IZA World of Labor, 208. https://doi.org/10.15185/izawol.208

Ivakhnyuk, I. (2013). The Russian migration policy and its impact on human development. Human Development Reports. Retrieved October 25, 2020, from http://hdr.undp.org/en/content/russian-migration-policy-and-its-impact-human-development

Karabchuk, T., \& Salnikova, D. (2017). The economic impact of migration in the Russian Federation: Taxation of migrant workers. Asia-Pacific Population Journal, 32(2), 137-174. https://doi.org/10.18356/839a8861-en

Lazareva, O. (2015). Russian migrants to Russia: Assimilation and local labor market effects. IZA Journal of Migration, 4, 20. https://doi.org/10.1186/s40176-015-0044-9

Lazareva, O., \& Sonin, K. (2008). Russian migrants to Russia: Choice of location and labor market outcomes. Working Papers, w0117. Retrieved October 25, 2020, from https://ideas.repec.org/p/abo/neswpt/w0117.html 
Lundborg, P. (2013). Wage effects of immigration in a bargaining economy. SULCIS Working Papers. Stockholm University, Linnaeus Center for Integration Studies - SULCIS. Retrieved October 25, 2020, from https://econpapers.repec.org/RePEc:hhs:sulcis:2013_002

Manacorda, M., Manning, A., \& Wadsworth, J. (2012). The impact of immigration on the structure of wages: Theory and evidence from Britain. Journal of the European Economic Association, 10(1), 120-151. https://doi.org/10.1111/j.1542-4774.2011.01049.x

Nyberg-Sørensen, N., Van Hear, N., \& and Engberg-Pedersen, P. (2002). The migrationdevelopment nexus evidence and policy options state-of-the-art overview. International Migration, 40(5), 3-47. https://doi.org/10.1111/1468-2435.00210

Ottaviano, G.I.P., \& Peri, G. (2012). Rethinking the effect of immigration on wages. Journal of the European Economic Association, 10(1), 152-197. https://doi.org/10.1111/j.15424774.2011.01052.x

Pesaran, M.H., \& Smith R. (1995). Estimating long-run relationships from dynamic heterogeneous panels. Journal of Econometrics, 68(1), 79-113. https://doi.org/10.1016/03044076(94)01644-F

Pesaran, M.H., Shin, Y., \& Smith, R.P. (1999). Pooled Mean group estimation of dynamic heterogeneous panels. Journal of the American Statistical Association, 94(446), 621-634. https://doi.org/10.1080/01621459.1999.10474156

Portes, J. (2019). The economics of migration. Contexts, 18(2), 12-17. https://doi.org/10.1177/1536504219854712

\section{Сведения об авторах / Bio notes}

Валей Азамат, кандидат экономических наук, Центр экономических исследований и послевузовского образования - Институт экономики, Карлов университет; старший научный сотрудник, доцент, Уральский федеральный университет. ORCID: 0000-00029583-6542. E-mail: azamat.valey@urfu.ru

Мамман Сулейман O., научный сотрудник, лаборатория международной и региональной экономики, Высшая школа экономики и менеджмента, Уральский федеральный университет. ORCID: 0000-0003-3204-0595. E-mail: onimisism@gmail.com
Azamat Valei, $\mathrm{PhD}$ in Economics, Center for Economic Research and Graduate Education Economics Institute (CERGE-EI), Charles University; senior researcher, Associate Professor, Ural Federal University. ORCID: 0000-00029583-6542. E-mail: azamat.valey@urfu.ru

Suleiman O. Mamman, researcher, Laboratory for International and Regional Economics, Graduate School of Economics and Management, Ural Federal University. ORCID: 00000003-3204-0595. E-mail: onimisism@gmail.com 